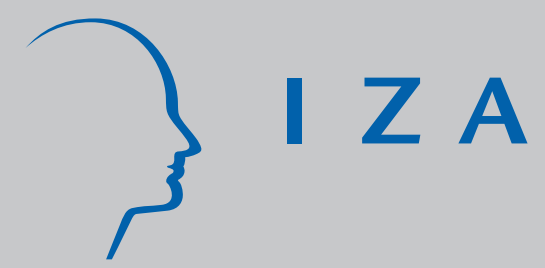

IZA DP No. 8976

Improving the Allocation of Spots in Child Care Facilities for Toddlers in Germany: A Mechanism Design Approach

Sissa Carlsson

Stephan L. Thomsen

April 2015

Forschungsinstitut zur Zukunft der Arbeit Institute for the Study of Labor 


\title{
Improving the Allocation of Spots in Child Care Facilities for Toddlers in Germany: A Mechanism Design Approach
}

\author{
Sissa Carlsson \\ NIW Hannover \\ and Leibniz Universität Hannover \\ Stephan L. Thomsen \\ NIW Hannover, \\ Leibniz Universität Hannover, ZEW and IZA
}

Discussion Paper No. 8976

April 2015

IZA

P.O. Box 7240

53072 Bonn

Germany

Phone: +49-228-3894-0

Fax: +49-228-3894-180

E-mail: iza@iza.org

Any opinions expressed here are those of the author(s) and not those of IZA. Research published in this series may include views on policy, but the institute itself takes no institutional policy positions. The IZA research network is committed to the IZA Guiding Principles of Research Integrity.

The Institute for the Study of Labor (IZA) in Bonn is a local and virtual international research center and a place of communication between science, politics and business. IZA is an independent nonprofit organization supported by Deutsche Post Foundation. The center is associated with the University of Bonn and offers a stimulating research environment through its international network, workshops and conferences, data service, project support, research visits and doctoral program. IZA engages in (i) original and internationally competitive research in all fields of labor economics, (ii) development of policy concepts, and (iii) dissemination of research results and concepts to the interested public.

IZA Discussion Papers often represent preliminary work and are circulated to encourage discussion. Citation of such a paper should account for its provisional character. A revised version may be available directly from the author. 
IZA Discussion Paper No. 8976

April 2015

\section{ABSTRACT}

\section{Improving the Allocation of Spots in Child Care Facilities for Toddlers in Germany: A Mechanism Design Approach}

The undersupply of spots in German daycare facilities for toddlers challenges parents' possibilities to work. To ease the situation, the government implemented a new law entitling every child between ages one and three to daycare supervision for about four hours per day. Nevertheless, the stressed situation of matching demand and supply does not only result from limited spaces but also from inefficient allocation. By means of simulations under different scenarios, we contrast a stylized version of decentralized allocation to a centralized allocation mechanism which applies a deferred-acceptance algorithm. This centralized system results in better and faster matches.

JEL Classification: $\quad$ C78, D82, J13

Keywords: allocation mechanism, deferred-acceptance algorithm, early education, child care

Corresponding author:

Stephan Thomsen

NIW Hannover

Königstr. 53

D-30175 Hannover

Germany

E-mail: thomsen@niw.de 


\section{Introduction}

Spots in daycare centers (Kindertagesstätten) for toddlers (children under three years of age) are a scarce resource in Germany. Whereas only $27.6 \%$ of these children were supervised in daycare in 2012 (Federal Statistical Office, 2012a), the federal government stated a demand of supervision for about 39\% (Federal Ministry of Family Affairs, Senior Citizens, Women, and Youth, 2013). These enrollment rates in daycare for toddlers also lie substantially below the OECD average 1 The undersupply of child care has various consequences. Chevalier and Viitanen (2002) find that the lack of daycare spots confines women's labor market activities while daycare supply seems unresponsive to an increasing demand. Similarly, Berlinski and Galiani (2007) provide evidence that subsidizing pre-primary education (or formal child care as in Müller et al. (2013) or Bonin et al. (2013)) increases maternal employment. Also, Haan and Wrohlich (2011) show that a raise in child care subsidies, conditioned on employment however, boosts women's labor supply. With respect to early school availability, Goux and Maurin (2010) find a sizable employment effect only on single mothers. Impeding the entry or the remaining in the labor market hampers mothers' opportunities to pursue a professional career and thus, their independence. Involuntarily forgone job opportunities (in part or completely) imply particularly large opportunity costs for the highly-skilled. Impeding qualified labor is especially counterproductive in the light of rising skilled worker shortages. According to official calculations, extending women's labor supply provides the largest potential to tap skilled labor within Germany (Federal Ministry of Labour and Social Affairs, 2015).

Since non-working citizens do not pay income taxes or social security contributions, the individual costs also translate into costs for society. Costs of welfare may increase in addition due to a higher likelihood of need of support from welfare or, if not immediately, then maybe at retirement age due to limited pension claims and therefore necessary subsidies (see OECD (2012) or Spieß et al. (2002) for respective calculations for Germany). Furthermore, (extensive) high quality early childhood education is perceived to promote the chances of children with disadvantaged socio-economic backgrounds (e.g. Heckman and Masterov, 2007; Schütz et al., 2008), as reported for instance for the Perry Preschool Program (e.g. Belfield et al., 2006). However, Felfe and Lalive (2012) find that in Germany it is so far rather the children with advantageous socio-economic backgrounds that attend daycare.

To mitigate the demand-supply-mismatch, the German government has passed a law to increase the number of daycare spots. ${ }^{2}$ From August 1, 2013 onwards every child between one and three years of age is entitled to daycare supervision for about four to five hours per day

\footnotetext{
${ }^{1}$ For the year 2008, the OECD (2011) reports a German enrollment rate of $17.8 \%$ for the under-three-yearolds while the OECD average was $30 \%$. Although country-specific enrollment rates change when adjusted for care intensity (number of hours per week a child attends daycare), this does not affect Germany's below-average ranking with respect to the enrollment rate of toddlers. Nonetheless, German enrollment rates in child care have been increasing compared to 2008.

${ }^{2}$ Badelt and Weiss (1990) discuss the issue of competitive institutional variety fostering product differentiation (rather than a single institution market with e.g. a governmental provider) which can further be expected to better meet the heterogenous demand by daycare consumers, given universal accessability to such 'product' variations.
} 
(like the children between three years of age and their first day at school). However, a still remaining problem is that spots in child care are often inefficiently distributed. The inability to quickly match the excess demand to the scarce supply results in lengthy placement procedures and planning insecurity.

Both limitations of the German daycare system, i.e. inefficient allocation and the lack of a sufficient number of spaces, are subject of an ongoing public debate. To give anecdotal examples, the newspaper "Die Welt" wrote on December 19, 2011 that in Munich "[...] waiting periods of 1.5 to 2 years lead women to register their child [at daycare centers] already during the first weeks of pregnancy". Similar issues were reported in 2013 for Berlin, e.g. in the newspaper "Berliner Morgenpost" on July 31, 2013. Problems with placements of toddlers in child care can further grow if the total number of births suddenly exceeds the expectations of the tightly and inflexibly planned system, as it was recently described in the newspaper "Hannoversche Allgemeine Zeitung" on March 24, 2015. Of course, these examples are only the tip of the iceberg but highlight that the debate has been going on for years and in very different regions. In line with that, the German online portal on daycare for parents, nursery teachers and daycare center staff recommends early registration for daycare spots as waiting times can take up to two years $3^{3}$ Despite this fact, however, official or representative statistics on waiting times are lacking in Germany.

In most cases, the allocation of children to daycare centers is organized in a decentralized way and there is usually no official institution that keeps track of all available and occupied daycare spots. Moreover, decentralized allocation is rather heterogeneous such that daycare centers act independently based on different assignment systems and possess a large discretion in choosing applicants. As a result, the placement of children can take numerous months to be completed. It is thus desirable to improve the speed and matching quality under the current allocation processes.

This paper provides a comparison of the placement success under decentralized allocation and an alternative centralized mechanism (allowing for faster matching and stronger incorporation of parents' preferences) by means of simulations that are based on different scenarios, varying numbers of child care centers, and different numbers of available daycare spots 4 As centralized mechanisms are not automatically better than decentralized ones (Roth, 1991), an efficient algorithm has to cope with strategy proofness and the stability of matches. Strategy proofness can be regarded as fulfilled if no party has an incentive to exercise a strategy that leads to a different outcome than the intended one. That is, parties are supposed to behave in an intended way, namely expressing true preferences. The challenges of centralized matching systems are discussed for example by Braun et al. (2010) with respect to admission practices for higher education in Germany. Still, Roth (1982) finds that it is impossible to achieve stability and strategy proofness at the same time. It is, however, possible to establish strategy proofness for one of two parties involved in the matching and to obtain stable matches simultaneously.

\footnotetext{
${ }^{3}$ See website of online portal, www.kita.de.

${ }^{4}$ We introduced a very simplified centralized allocation mechanism in Carlsson and Thomsen (2014).
} 
To the centralized system, we therefore apply the so-called deferred-acceptance algorithm (first formally outlined by Gale and Shapley (1962), who describe the college admission problem, that is similar to the case at hand) because it achieves stable and, from the proposers' point of view, optimal assignments of applicants and allows for partial strategy proofness. We further adopt a so-called clearinghouse to be in charge of the matching process. This has also been done by Abdulkadiroglu et al. (2005), who apply a student-proposing deferred-acceptance algorithm with some alterations to match students to high schools in New York. As opposed to the college admission problem, in which colleges are treated as agents with own preferences over students, in the school choice case schools are regarded as consumption objects that can simply express priorities with respect to applicants (Abdulkadiroglu and Sönmez, 2003). As a realistic setup of the German daycare system, we employ a mixture of both: daycare centers formulate (rather broad) rankings but are considered as agents due to their powerful position in a situation of excess demand for child care.

The comparison of the allocation results shows that the centralized mechanism matches more children to their first choice daycare centers compared to the decentralized method, regardless of how the underlying conditions are chosen. Furthermore, no child receives a spot in a daycare center below her second choice whereas a certain share of the allocated children is always matched to their least desired daycare facility under the decentralized system. Moreover, the centralized mechanism proceeds much faster and is easier to carry out since all decisive information is available to the coordinating central clearinghouse from the very beginning such that the whole process requires no interruptions in need of information acquisition as under the decentralized system.

The remainder of this paper is organized as follows. Section 2 provides more information on the current daycare situation in Germany. Our methodology of how the allocation process works under both systems is outlined in Section 3. Section 4 describes the simulation, including the generated data set and the variables used. The corresponding results are presented in Section 5 , followed by a discussion and interpretation in Section 6 . The final section concludes.

\section{The German daycare system}

As the responsibility for daycare provision in Germany lies at the community level (with no overall common guideline for regulations at a higher level), there is no uniform German daycare system. Instead, there is a broad spectrum with large differences on the supply side (but also on the demand side). This very heterogeneous structure of "the" German daycare system firstly becomes apparent in terms of the extent to which daycare supervision for toddlers is actually used. While the daycare enrollment ratio for toddlers increased on average from 40 to $50 \%$ in East-Germany over the period from March 2006 to March 2012, the respective ratio rose from merely 8 to $23 \%$ in West-Germany according to Federal Ministry of Family Affairs, Senior Citizens, Women, and Youth (2013). Thus, the estimated average demand of $39 \%$ does not 
adequately mirror these significant regional differences 5 The large East-West disparity may be attributed predominantly to different historical backgrounds regarding mothers' or more generally women's labor force participation. It was much higher in the GDR than in WestGermany and there were also more child care facilities available $\sqrt[6]{6}$ Furthermore, the demand for daycare supervision can easily exceed the supply in metropolitan areas since female labor force participation and agglomeration of young families tend to be higher there than elsewhere (Federal Ministry of Family Affairs, Senior Citizens, Women, and Youth, 2013).

Secondly, the German daycare system differs with respect to how the allocation of daycare spots to children is organized. Based on certain features, such as the existence of a central institution coordinating the allocation process and a consistent application deadline as well as the degree to which the application of children and the report of available spots are centrally handled, the different mechanisms in place can be characterized as "centralized" and "decentralized". Due to the lack of official information on these organizational matters, we contacted the municipalities of all German cities with more than 120,000 inhabitants between December 2012 and June 2013 (Table 1): our analysis indicates that in about $70 \%$ of the cases a form of decentralized allocation is used 7

$<$ Include Table 1 about here $>$

\section{Methodology}

By means of simulations, we compare the placement success under decentralized allocation with the one under an alternative centralized mechanism for which we employ an applicantproposing deferred-acceptance algorithm. The two allocation methods, centralized and decentralized, can be described as follows. To begin with, both models are preceded by a form of interview/application period. Thereby, parents and their children can get to know the daycare facilities where the children can be enrolled while the daycare centers' staff can form an opinion about their applicants. Formally or informally, both parties then formulate rank orders of the respective opposite based on personal preferences. At this point, the actual modeling of the allocation procedures sets in.

Under the decentralized allocation system, the daycare centers' staff offer their spots to the first $q_{k}$ of $n$ applying children on their ranking lists, whereby $q_{k}$ indicates the available capacity $q$ at a given daycare facility $k$. Note here that based on the selection criteria chosen by the daycare centers' staff and due to simultaneously issued applications, the total number of proposed spots

\footnotetext{
${ }^{5}$ For a detailed statistical overview with consideration of the single federal states, see Federal Ministry of Family Affairs, Senior Citizens, Women, and Youth (2013).

${ }^{6}$ With regard to data published by the Federal Statistical Office (1992), Adler and Brayfield (1997) state that "most of the $91 \%$ employed women in the East worked full-time, whereas only about three quarters of the $58 \%$ in the West did so" (p. 248).

${ }^{7}$ A clear-cut differentiation into either category is rather complicated, however, as our questions have been answered differently even within groups of municipalities with rather centralized or decentralized mechanisms respectively. Therefore, a simplified differentiation into rather "centralized" or more "decentralized" allocation systems serves as the basis of our comparison of the mechanisms.
} 
may be larger than the number of children actually receiving an offer. Some children therefore get to choose between proposals based on their rank order. At this point, this first allocation round needs to be interrupted for some time in order to receive a confirmation or a declination from the parents regarding an offered spot. Hence, in this mechanism, parents'/children's preferences remain private information to the allocating institution(s) - the daycare centers until this point of partial elicitation 8 After this information has been enquired, the process can continue. The daycare facilities allocate their confirmed spots to the respective children and delete the other initially selected children from their lists which frees up capacity again. These newly freed-up spots are then proposed to the next children on the daycare centers' lists in the second round. As in the first round, the total number of proposed spots may be larger than the number of children receiving an offer. The process has to be interrupted again to obtain confirmations or declinations from parents. After the information has been enquired, the daycare facilities allocate their confirmed spots to the respective children and delete the other children from their lists. Non-confirmed spots become available again and the second round is terminated. This procedure continues until all available daycare spots are allocated to children and no child occupies more than one spot. With this stylized decentralized allocation system we try to replicate mechanisms currently applied in practice, combining their most salient elements.

Unlike the decentralized allocation procedure, the centralized mechanism puts an independent central clearinghouse in charge of the allocation process, as implemented e.g. by Abdulkadiroglu et al. (2005). The clearinghouse thereby receives all rank order lists at the beginning of the allocation process (direct revelation of preferences). In line with the Gale and Shapley (1962) (applicant-proposing) deferred-acceptance algorithm, this mechanism starts with the children applying to their first choice daycare center 9 The latter consecutively select their most preferred applying children (up to $q_{k}$ of $n$ applicants, whereby $q_{k}$ indicates the available capacity $q$ at a given daycare facility $k$ ). The unselected children get rejected and have to apply to their second most preferred daycare facility. The latter gets to choose again among the already selected children and the new applicants while rejecting the rest. Rejected children have to apply again to the next daycare center on their list and so on. The mechanism stops when no further rejections are issued. Since the clearinghouse takes care of the whole allocation process with all necessary information at its disposal, the procedure requires no lengthy interruptions and can be carried out in one go as opposed to the decentralized mechanism. With this centralized mechanism we do not aim at reconstructing a system that is already in place in Germany but at setting up a new one.

As an advantage compared to other algorithms, the deferred-acceptance mechanism achieves

\footnotetext{
${ }^{8}$ The entire rank order list set up by parents/children will never be known.

${ }^{9}$ In the college admission example by Gale and Shapley (1962), all students apply first to their favorite college, which preliminarily selects its most preferred students (up to its full capacity or all students if there are fewer applicants than seats available) and rejects the rest. All rejected students then apply to their next most preferred college. The college in turn selects again its most preferred students from the pool of the new and already selected applicants and rejects the rest. The process ends when every student has either been selected by one college or rejected by all colleges to which she would be willing and allowed to apply. Final matches between colleges and their selected students can then be accomplished.
} 
stable and, from the proposing party's point of view, optimal assignments of applicants (Gale and Shapley, 1962). Gale and Shapley (1962) define that "an assignment of applicants to colleges will be called unstable if there are two applicants $\alpha$ and $\beta$ who are assigned to colleges $A$ and $B$, respectively, although $\beta$ prefers $A$ to $B$ and $A$ prefers $\beta$ to $\alpha$ " (p. 10). A condition of being accepted by a lower ranked daycare facility is that the child has already been rejected by more preferred facilities because other children with higher ranking positions have been occupying all available spots there. Hence, justified envy (discussed e.g. by Abdulkadiroglu and Sönmez, 2003) is eliminated. Furthermore, parents/children have no incentive to state their preferences strategically as the parents' order of ranking of the daycare centers has no influence on the probability of being admitted by a certain facility. In the decentralized system, parents do not have incentives to act strategically either: they will apply to as many daycare centers as possible (there is no limit) in order to enhance their chances to obtain a spot. They do not benefit from truncating their application list because limiting the matching options does not increase the probability that any of these few matches will actually occur. Truncating only enhances the overall probability of ending up without a daycare spot in the case of undersupplied child care. Postponing a daycare application to some future period is possible but since parents have no information about their future competitors either, waiting is also not a strategic option to secure a particulary desired spot in child care. Switching spots in some later application period might be possible, however, but only if a newly(!) issued application to a preferred child care facility was successful. Although strategy proof - at least from the applicant's perspective - stability of the matches is not given. We will come back to this part in the discussion.

\section{Simulation description}

We simulate the described centralized and decentralized mechanisms to analyze their outcomes regarding their matching quality. That is, by means of simulation, we want to examine whether children are eventually matched to personally more preferred daycare centers under the centralized method than under the decentralized one. The simulations are based on an artificial data set which takes into account the relevant factors of placement decisions. Additionally, we set up the following five assumptions:

1. There is a standardized application period such that all parents register their children at the same time.

2. Determinants, based on which daycare centers choose their applicants, are clearly defined.

3. The daycare centers are of about equal size.

4. Families that have already accepted a spot under the decentralized mechanism receive no new offers by other daycare facilities.

5. A spot even in the least preferred daycare facility is considered preferable to receiving no spot at all. 
Regarding assumption 1, our investigations indicated that in practice only about one municipality in three has a commonly agreed-upon deadline. However, a standardized application period contains the advantage of improved transparency and is therefore assumed in the simulations. In line with that, assumption 4 becomes realistic because it is rational for the staff to wait until the end of the indicated reflection period granted to parents, to collect all declinations by parents first before making new offers instead of immediately reacting to every new parental reply separately. We also assume that acceptances in form of contracts are binding and public.

The variables that we include are selected on the basis of what we find to be important drivers in the actual matching process (Table 2). We consider five child characteristics that we describe here in declining order of relevance to the admission decisions of the daycare centers' staff (Panel A). A generally valid priority level splits the children into eight groups based on their parents' occupational involvement. This classification is based on the "general admission criteria for daycare facilities with the city of Hanover as the funding body" by the Department of Youth and Family (2004). Yet, since every toddler is now entitled to daycare supervision, the occupational situation of the parents should be insignificant to the procedure. However, in case of remaining undersupply, the children of single parents or of parents that are both working are still likely to be given priority over children whose parents could also supervise them at home during the day. At least for children younger than one year of age some priorities are laid down by law (German Social Code, 2013) 10 Next, we consider whether a child already has a sibling at a daycare center. Hereby, we assume that parents will always rank a daycare center as first choice if their child's sibling is already enrolled there. Thus, if no sibling is enrolled in the favorite daycare facility, then there will also be no sibling enrolled in any other facility. Furthermore, children with present siblings are preferred by a daycare center because the staff is already acquainted with the family. The daycare centers may further have different preferences for a child's personality. Hence, this subjective (and often unconscious) personality rating can vary between daycare centers and cannot be anticipated by the parents. Additionally, we include the distance between a child's home and the location of the different daycare facilities. We assume that shorter distances are preferred by parents as well as by the daycare centers. In case that daycare centers are still indifferent between two or more children, a personal id number, assigned to every child, can be applied as a single tie-breaker.

\section{$<$ Include Table 2 about here $>$}

According to these child characteristics, the daycare facilities formulate their rankings. Analogous to these, we add the variable choice, which reflects parents'/children's preferences over the daycare centers. We base this variable exclusively on the distance to the daycare facilities. Consequently, distance determines the order of choices which in turn correlates with having a sibling in the favorite daycare facility. The parties' preferences underlying their rankings conform to the assumptions of completeness, transitivity, and independence.

\footnotetext{
${ }^{10}$ For the sake of simplicity, we assume that daycare facilities actually stick to these legal requirements. Yet, this could be verified by a central clearinghouse.
} 
Overall, we examine the outcomes of the centralized and decentralized allocation for three different scenarios which we refer to as "Basic", "Random", and "Top". We analyze all scenarios under the conditions of having 1) 3 daycare facilities, 2) 5 daycare facilities, and 3) 10 daycare facilities. These conditions are in turn simulated for 100 children applying to a total of a) 50 available spots, b) 65 available spots, and c) 90 available spots. The scope of the supply of child care for respectively $50 \%, 65 \%$, and $90 \%$ of the applying children relate to data of the Federal Statistical Office (2012b) published by the Federal Ministry of Family Affairs, Senior Citizens, Women, and Youth (2013). According to the data, approximately $90 \%$ of the applying children are covered on average by child care in East Germany. In West Germany, the majority of states covers on average between $60 \%$ and $70 \%$ of interested children while two states provide child care on average for slightly more than $50 \%$. Hence, in all cases, some children will always end up without daycare supervision due to excess demand. We assume further that the total number of available spots is approximately equally distributed among the existing daycare centers. All described case variations use 200 replications, each with a new seed set for every new replication.

The "Basic" scenario considers the information in Panel A of Table 2 for the assignment process. The "Random" scenario adds the random-variable of Panel B of Table 2 to the general/basic outline. In this scenario, we investigate how our results change if

1. some children apply to only 2 instead of all 3 daycare facilities,

2. some children apply to only 3 or 4 instead of all 5 daycare facilities,

3. some children apply to only 6 or 8 instead of all 10 daycare facilities.

The "Top" scenario simulates the situation in which daycare center 1 is located in an area of high population density such that it is the closest and thus most popular daycare facility for most children. (In the other scenarios, the distance to the different daycare centers is randomly distributed.)

\section{Results}

Apart from the fact that the centralized mechanism with its applicant-proposing deferredacceptance algorithm is much faster and easier to be carried out than the decentralized method, the centralized system also accomplishes "better" matches. That is, a larger share of allocated children is matched to personal first and second choice daycare centers than under the decentralized mechanism (Table 3). The size of these shares thereby depends on the underlying assumptions of the simulated scenarios. Our results can be summed up as follows:

1. Consistent across all scenarios, number of daycare centers, and number of overall available daycare spots is the finding that all children are exclusively allocated to either their first or second choice daycare facility under the centralized mechanism whereas a certain fraction of children is always allocated to even the least preferred daycare center under the decentralized system. 
2. The share of children matched to their first choice daycare facilities is always higher under the centralized than under the decentralized mechanism.

3. In the "Basic" and "Random" scenarios the shares of children allocated to their first choice daycare centers are much larger than those of the children matched to their second choices, both under the centralized and the decentralized system. The respective shares are even of the same sizes for the two scenarios under the centralized mechanism, indicating that the truncations of choice lists have no impact on the overall outcome.

In the "Top" scenario in contrast, the majority of the allocated children is matched to their second choice daycare facilities under the centralized mechanism. For the decentralized system, this finding only holds when considering the cases of 3 daycare facilities and, on average, 5 daycare centers but not when regarding the case of 10 daycare centers.

4. Raising the number of daycare facilities while keeping the total number of available daycare spots constant decreases the share of children matched to their first choice daycare facilities for all cases in the "Basic" and "Random" scenarios, under both the centralized and the decentralized mechanisms.

For the "Top" scenario, this holds also under the decentralized system. Under the centralized method, we find this decrease only when raising the number of daycare centers from 3 to 5 . The shares of children matched to their first choice daycare facilities when considering 10 daycare centers are, however, about as high as or even higher than when regarding only 3 daycare centers.

5. The increase in the total number of available daycare spots when keeping the number of daycare facilities constant increases (or at least shows an increasing tendency in) the fraction of children allocated to their first choice daycare centers within the "Basic" and the "Random" scenario for both the centralized and decentralized mechanisms. Yet, the increase is not large.

The results of the "Top" scenario are mixed. In the case of 3 daycare facilities, the share of children matched to their first choice daycare center is highest for 65 available spots for both the centralized and the decentralized system. In the cases of 5 and 10 daycare centers, the shares decline with an increase in the total number of available spots under the centralized method while there is no commonality under the decentralized system.

$<$ Include Table 3 about here $>$

\section{Discussion}

The centralized mechanism produces better matches especially for the children, who represent the applicant side here, than the decentralized mechanism. This can be explained as follows: the centralized system turns the children towards their favorite daycare center first. Hence, 
even if they get rejected by their first choice due to the facility's preference for other children, they have at least been considered. Furthermore, a daycare center knows that an applying child will be satisfied with the offered spot because parallel offers cannot occur such that an outstanding application is always the most favored option of the ones remaining. Additionally, in the centralized system, at least partial strategy proofness is ensured because parents' order of application to the daycare centers has no influence on the probability of being admitted by a certain facility. Yet, in the absence of close supervision through a central clearinghouse in charge of the allocation, daycare centers could conceal their actual capacities in order to reserve daycare spots for children of high preference, thus, circumventing the system. Similar to Roth (1982), Sönmez (1997) finds that "there is no solution that is stable and non-manipulable via capacities" (p. 198).

The decentralized system in contrast causes bottlenecks by incentivizing parents to register their children at all (or at least multiple) daycare centers at once. Parents cannot afford to wait to issue sequential applications because daycare centers that have already allocated all their available spots will not consider an additional child even if the child is preferred to already accepted children. Thereby, long waiting lists in all daycare centers are created that are only shortened when highly ranked and thus, multiply admitted children decline less preferred offers. Depending on these children's preferences, it is thus possible that a wait-listed child receives and consequently accepts an offer from a daycare facility the child has little preference for before she rises high enough on the waiting list of her favorite daycare center. This can lead to unstable matches if the respective daycare facility would also prefer that child over a child it might finally admit instead. We assume here that parents who have already accepted a daycare spot under the decentralized system receive no further offers. Also, they would accept an offer even from the lowest ranked daycare center rather than risk not receiving a spot at all. In reality, however, delaying final decisions may be rewarded as the various daycare centers have different application timings and deadlines.

Another advantage of the centralized mechanism is that it executes the matching process much faster than the decentralized one. This is due to the fact that the central clearinghouse has all necessary information at its disposal from the very beginning and is the sole institution in charge of the allocation decisions. Consequently, there is no need to interrupt the process in order to enquire parents' confirmation or declination of offered daycare spots whereas interruptions are necessary under the decentralized system. Together with the creation of the aforementioned bottlenecks, these interruptions, which can take multiple days or even weeks depending on the different application rules (turnaround time is for instance discussed by Roth and Xing, 1997), significantly slow down and defer the decentralized matching process. The cost resulting from the deferment under the decentralized system can thus be interpreted as the cost of asymmetric information. Under the fast centralized mechanism, children would not have to be registered for daycare spots so far ahead of schedule. The tendency of ever earlier market transactions is, for example, described by Roth and Xing (1994). 
The differences in the matching results between our "Basic" and "Random" scenarios, on the one hand, and the "Top" scenario, on the other hand, first off all originate from the fact that the latter scenario produces new bottlenecks since one particular daycare center is favored by most families. Hence, a smaller share of children can be allocated to their first choice daycare center. For a relatively small number of daycare centers, this results in the majority of children being matched to their second choice daycare facilities. In our case of 10 daycare centers these results deviate, however, for the decentralized system.

The main differences between the two systems found in reality can be condensed as follows: a decentralized system leaves the allocation decision principally to the daycare facilities. The higher the children to daycare spots ratio and the less transparent the process is, the larger the daycare centers' bargaining power thereby becomes. The centralized mechanism, on the other hand, also allows parents to claim their preferences. Furthermore, asymmetric information constitutes risk and uncertainty for the daycare facilities and families under the decentralized mechanism. This obstacle is overcome in the centralized system by guaranteeing the exchange of decisive information through the clearinghouse. This results in less administrative effort for the daycare staff, lower search costs for parents, and ensures that spots are no longer blocked via multiple admissions, such that it works faster and more easily. Parents can return sooner to the labor market which in turn reduces their opportunity cost and also economic costs.

Although returns on investment in child care might look small in the short run, they can be large in the long-run. In their study on safeguarding of skilled labor via family policies, Geis and Plünnecke (2013) estimate that if child care was exhaustively provided in Germany, allowing more mothers of children younger than 12 years to work, the supplementary female labor supply could render an additional income tax revenue as well as social security contributions of a maximum of 18 billion EUR a year. This outweighs the forecasted cost of 14 billion EUR per year that would likely be necessary to raise daycare supply to sufficiently high numbers. A more modest assumption in terms of an increase in female labor supply is estimated to result in extra state revenues of only 4 billion EUR a year. However, if fewer mothers demanded daycare, fewer spots in child care would be needed (Geis and Plünnecke, 2013), thus, leading to lower costs.

A similar but more extensive study addressing additional state revenues due to daycare expansion is carried out by Spieß et al. (2002). They do not only take additional income tax revenues and social security contributions into account but also consider the income effects of additional daycare staff as well as lower required spending for mothers on welfare. Furthermore, as Geis and Plünnecke (2013) state, higher investment in early childhood programs will pay off in the long run despite higher short term costs, e.g. due to a better educated work force. In this respect, Heckman and Masterov (2007) declare that the "estimated rate of return to the Perry Preschool Program is 16\%. This includes benefits from reduced remediation and reduced crime, as well as the increased earnings of the participant" (p. 488). Finally, firms would also benefit from an expansion of child care when they can count on qualified mothers in their team instead of relying on temporary substitutes. 


\section{Conclusion}

The scarcity of daycare spots for toddlers in Germany is a big challenge for many working parents. In order to alleviate the shortage and to facilitate the compatibility of job and child care for more parents, the German government has initiated a new law based on which every child between one and three years of age is entitled to daycare supervision for about four to five hours per day from August 1, 2013 onwards. However, inefficient allocation of daycare spots under time constraints can have similar negative effects as undersupply. Thus, utilizing a simulated data set, this paper analyzes whether a centralized allocation mechanism outperforms the decentralized allocation system being frequently used in Germany. Based on our simulations' results, we conclude that the centralized mechanism is much faster to be carried out and accomplishes on average more satisfactory matches due to incorporating all involved parties' preferences early on.

Given that, an efficient allocation system could look like the following: all parents register their children on a website administered by a central clearinghouse. The implementation of such a clearinghouse in the German daycare system is, until now, much more realistic at the community level than at the state level for instance because it is the communities that are in charge of daycare related matters. It would be welcome, however, if centralized allocation was not restricted to community borders, especially in case that parents require a large amount of flexibility. Parents then provide information on the child's name, age, sex, and address and signify whether the child has special supervisory needs (e.g. if the child is disabled or has linguistic and/or social deficiencies). Additionally, the parents can name whether their child already has siblings at a given daycare facility and whether they request that all their children be supervised by the same daycare center. Moreover, the occupational and family situations are of central importance for the allocation order. Parents should also indicate their employers' name and address, their working hours, including the time to commute to and from work, as well as whether they are single parents or whether they live together. Finally, the parents need to specify on what days, for how many hours, and over what period of time their child is to attend daycare. Based on the information provided, the system searches for adequate daycare facilities within a certain radius around the child's home and on the route the parents take to get to their respective work places. The parents and their children are then invited to Open Days in order to get to know the daycare facilities and vice versa. Afterwards, the parents are asked to create a ranking of the suggested daycare facilities which is then saved and submitted to the system.

In order to also take the daycare centers' preferences into account, the staff members have to submit a ranking as well, indicating what children with what characteristics they would prefer, and declare how many daycare spots they have available. However, the daycare facilities' rankings have to be in line with the priority levels such that children whose parents are both working are to be allocated with priority as opposed to children whose parents could also supervise them at home. This condition can be ensured by the fact that a clearinghouse takes care 
of the final allocation and thus receives all child and daycare related information together with the submitted ranking lists. Hence, it would find out immediately if a child with high priority is ranked lower than she ought to be. After a fixed deadline, all applications and rankings are considered and the actual allocation process starts. The applicant-proposing deferred-acceptance algorithm of the centralized mechanism stops when no rejections of children can be issued anymore. Those children who have not been assigned a spot are placed on waiting lists. As some families are still likely to move to other cities after daycare spots have been allocated, some occupied spots may become available again. To take care of such situations, it is reasonable (and possible time-wise due to the fast execution of matching) to conduct another application period. This might, however, jeopardize the concept of stable matches.

As opposed to our static mechanism with merely one time decision making for only one period in total, the matching problem has also been addressed with dynamic approaches (e.g. Kennes et al., 2014; Pereyra, 2013; Kurino, 2014). These dynamic matching models include two or more matching periods. In our opinion, however, switching child care spots in the German daycare system is not very likely due to the severe undersupply (the main point is to have a daycare spot at all), which thus makes the consideration of dynamic occupations of spots redundant in our case.

\section{References}

Abdulkadiroglu, A., P. A. Pathak, and A. E. Roth (2005): "The New York City high school match," American Economic Review, 95(2), 364-367.

(2009): "Strategy-proofness versus efficiency in matching with indifferences: Redesigning the NYC high school match," American Economic Review, 99(5), 1954-1978.

Abdulkadiroglu, A., And T. Sönmez (2003): "School choice: A mechanism design approach," American Economic Review, 93(3), 729-747.

Adler, M. A., And A. Brayfield (1997): "Women's work values in unified Germany: Regional differences as remnants of the past," Work and Occupations, 24(2), 245-266.

Badelt, C., And P. Weiss (1990): "Specialization, product differentiation and ownership structure in personal social services: The case of nursery schools," Kyklos, 43(1), 69-89.

Belfield, C. R., M. Nores, S. Barnett, and L. Schweinhart (2006): "The High/Scope Perry Preschool Program: Cost-benefit analysis using data from the age-40 followup," Journal of Human Resources, 41(1), 162-190.

Berliner Morgenpost (2013): "Was Berliner Eltern für einen Kita-Platz auf sich nehmen," http://www.morgenpost.de/berlin-aktuell/article118547168/ Was-Berliner-Eltern-fuer-einen-Kita-Platz-auf-sich-nehmen.html, retrieved 05.12.2013. 
Berlinski, S., And S. Galiani (2007): "The effect of a large expansion of pre-primary school facilities on preschool attendance and maternal employment," Labour Economics, 14, 665680.

Bonin, H., M. Clauss, I. Gerlach, I. Lass, A. L. Mancini, M.-A. Nehrkorn-Ludwig, V. Niepel, R. Schnabel, H. Stichnoth, and K. Sutter (2013): "Evaluation zentraler ehe- und familienbezogener Leistungen in Deutschland," Gutachten für die Prognos AG.

Braun, S., N. Dwenger, And D. KüBler (2010): "Telling the truth may not pay off: An empirical study of centralized university admissions in Germany," The B.E Journal of Economic Analysis 83 Policy, 10(1), (Advances), Article 22.

Carlsson, S., and S. Thomsen (2014): "Nicht ausgeschöpfte Potenziale in der KitaPlatzvergabe," Vierteljahreshefte zur Wirtschaftsforschung, 1 (83. Jahrgang), 183-198.

Chevalier, A., and T. K. Vittanen (2002): "The causality between female labour force participation and the availability of childcare," Applied Economics Letters, 9, 915-918.

Department of Youth and Family (2004): "Allgemeine Aufnahmekriterien für Kindertagesstätten in Trägerschaft der Landeshauptstadt Hannover," Hannover.

Die Welt (2011): "Die Kita-Suche nimmt absurde Züge an," http://www.welt.de/ regionales/muenchen/article13775772/Die-Kita-Suche-nimmt-absurde-Zuege-an . html, retrieved 05.12.2013.

Federal Ministry of Family Affairs, Senior Citizens, Women, and Youth (2013): "Vierter Zwischenbericht zur Evaluation des Kinderförderungsgesetzes," Berlin.

Federal Ministry of Labour and Social Affairs (2015): "Fortschrittsbericht 2014 zum Fachkräftekonzept der Bundesregierung," Berlin.

Federal Statistical Office (1992): "Datenreport 1992 - Zahlen und Fakten über die Bundesrepublik Deutschland," Bonn.

Federal Statistical Office (2012a): "Kindertagesbetreuung in Deutschland 2012," Wiesbaden.

Federal Statistical Office (2012b): "Statistiken der Kinder- und Jugendhilfe: Kinder und tätige Personen in Tageseinrichtungen und in öffentlich geförderter Kindertagespflege am 01.03.2012," Wiesbaden.

Felfe, C., And R. Lalive (2012): "Early child care and child development: For whom it works and why," pp. 1-44, Discussionpaper, University St. Gallen.

Gale, D., And L. S. Shapley (1962): "College admissions and the stability of marriage," American Mathematical Monthly, 69(1), 9-15. 
Geis, W., And A. Plünnecke (2013): "Fachkräftesicherung durch Familienpolitik," IWPositionen - Beiträge zur Ordnungspolitik aus dem Institut der deutschen Wirtschaft Köln, 60.

German Social Code (2013): "§24 SGB VIII: Anspruch auf Förderung in Tageseinrichtungen und Kindertagespflege," Berlin.

Goux, D., And E. Maurin (2010): "Public school availability for two-year olds and mothers' labour supply," Labour Economics, 17, 951-962.

HaAn, P., And K. Wrohlich (2011): "Can child care policy encourage employment and fertility? Evidence from a structural model," Labour Economics, 18, 498-512.

Hannoversche Allgemeine Zeitung (2015): "Krippenplätze werden knapp," .

Heckman, J. J., and D. V. Masterov (2007): "The productivity argument for investing in young children," Review of Argricultural Economics, 29(3), 446-493.

Kennes, J., D. Monte, and N. Tumennasan (2014): "The daycare assignment: A dynamic matching problem," American Economic Journal: Microeconomics, 6(4), 362-406.

Kurino, M. (2014): "House allocation with overlapping generations," American Economic Journal: Microeconomics, 6(1), 258-289.

Müller, K.-U., C. K. Spiess, C. Tsiasioti, K. Wrohlich, E. Bügelmayer, L. Haywood, F. Peter, M. Ringmann, and S. Witzke (2013): "Evaluationsmodul: Förderung und Wohlergehen von Kindern," DIW Berlin: Politikberatung kompakt, 73, Studie im Auftrag der Geschäftsstelle für die Gesamtevaluation ehe- und familienbezogener Maßnahmen und Leistungen in Deutschland, Prognos AG, für das Bundesministerium für Familie, Senioren, Frauen und Jugend und das Bundesministerium der Finanzen.

OECD (2011): "OECD Family Database," Paris.

OECD (2012): "Gender equality in education, employment and entrepreneurship," Paris.

Pereyra, J. S. (2013): "A dynamic school choice model," Games and Economic Behavior, $80,100-114$.

Rотн, A. E. (1982): "The economics of matching: Stability and incentives," Mathematics of Operations Research, 7(4), 617-628.

(1991): "A natural experiment in the organization of entry-level labor markets: Regional markets for new physicians and surgeons in the United Kingdom," American Economic Review, 81(3), 415-440.

Roth, A. E., And X. XING (1994): "Jumping the gun: Imperfections and institutions related to the timing of market transactions," American Economic Review, 84(4), 992-1044. 
(1997): "Turnaround time and bottlenecks in market clearing: Decentralized matching in the market for clinical psychologists," Journal of Political Economy, 105(2), 284-329.

Schütz, G., H. W. Ursprung, and L. Wössmann (2008): "Education policy and equality of opportunity," Kyklos, 61(2), 279-308.

Sönmez, T. (1997): "Manipulation via capacities in two-sided matching markets," Journal of Economic Theory, 77, 197-204.

Spiess, C. K., J. Schupp, M. Grabka, J. P. Haisken-De New, H. Jakobeit, and G. WAGner (2002): "Abschätzung der (Brutto-)Einnahmeeffekte öffentlicher Haushalte und der Sozialversicherungsträger bei einem Ausbau von Kindertageseinrichtungen," Berlin.

\section{Appendix: Description of the survey}

Our investigations, that consisted in interviews mostly by phone but also by mail, between December 2012 and June 2013 of more than 50 municipalities in Germany's largest cities with more than 120.000 inhabitants indicated that in about $70 \%$ of all cases a form of decentralized allocation is used. We base our categorization into "centralized" and "decentralized" on the following issues whereby we regard the first question as the most decisive one:

1. Is there any independent institution (neither parents nor daycare staff) that has an overview over completed contracts between families and daycare centers such that in case of multiple admissions a child can be automatically taken off of the waiting lists of less preferred daycare facilities?

2. Are children's applications centrally registered?

3. Are all available and occupied spots in state-run (that is, publicly operated and financed) daycare facilities centrally recorded?

4. Is there a fixed application deadline by which all children have to be registered?

As these questions have been answered differently even within groups of municipalities with systems that could be classified as centralized or decentralized respectively, a clear-cut differentiation into either category is rather complicated. Thus, we need to rely on relatively broad generalizations. 


\section{Tables}

Table 1: Daycare spot allocation systems in Germany's largest cities with 120.000 inhabitants or more*

\begin{tabular}{|c|c|c|c|c|c|c|}
\hline $\begin{array}{l}\text { Federal } \\
\text { State }\end{array}$ & City & $\begin{array}{l}\text { Independent } \\
\text { co-ordinating } \\
\text { institution }\end{array}$ & $\begin{array}{l}\text { Central } \\
\text { applica- } \\
\text { tion of } \\
\text { children }\end{array}$ & $\begin{array}{l}\text { Central reg- } \\
\text { istration } \\
\text { spots }\end{array}$ & $\begin{array}{l}\text { Fixed ap- } \\
\text { plication } \\
\text { deadline }\end{array}$ & System \\
\hline Schleswig- & Kiel & no & no & no & no & decentral. \\
\hline Holstein & Lübeck & no & no & yes & no & decentral. \\
\hline Hamburg & Hamburg & no & no & no & no & decentral. \\
\hline Lower- & Hanover & no & no & no & no & decentral. \\
\hline \multirow[t]{5}{*}{ Saxony } & Braunschweig & no & yes & yes & yes & decentral. \\
\hline & Osnabrück & no & no & no & yes & decentral. \\
\hline & Oldenburg & no & no & no & yes & decentral. \\
\hline & Wolfsburg & no & no & no & no & decentral. \\
\hline & Göttingen & yes & yes & yes & no & central. \\
\hline Bremen & Bremen & no & no & no & yes & decentral. \\
\hline North Rhine- & Cologne & yes & yes & yes & no & central. \\
\hline \multirow[t]{19}{*}{ Westphalia } & Düsseldorf & no & yes & no & yes & decentral. \\
\hline & Dortmund & no & no & no & no & decentral. \\
\hline & Duisburg & no & no & no & no & decentral. \\
\hline & Bochum & no & no & yes & no & decentral. \\
\hline & Wuppertal & yes & yes & yes & no & central. \\
\hline & Bonn & yes & yes & yes & yes & central. \\
\hline & Bielefeld & no & no & no & no & decentral. \\
\hline & Münster & no & no & no & yes & decentral. \\
\hline & Mönchengl. & yes & yes & no & no & central. \\
\hline & Gelsenkirchen & no & no & yes & no & decentral. \\
\hline & Krefeld & yes & yes & yes & no & central. \\
\hline & Oberhausen & no & no & yes & no & decentral. \\
\hline & Hagen & yes & yes & yes & yes & central. \\
\hline & Hamm & no & no & no & no & decentral. \\
\hline & Mülheim & no & no & yes & yes & decentral. \\
\hline & Herne & no & no & yes & yes & decentral. \\
\hline & Leverkusen & no & no & no & no & decentral. \\
\hline & Solingen & no & no & yes & no & decentral. \\
\hline & Paderborn & no & no & yes & no & decentral. \\
\hline \multirow[t]{4}{*}{ Hesse } & $\begin{array}{l}\text { Frankfurt } \\
\text { a.M. }\end{array}$ & no & no & no & yes & decentral. \\
\hline & Wiesbaden & no & no & no & no & decentral. \\
\hline & Kassel & no & no & yes & no & decentral. \\
\hline & Darmstadt & no & no & no & no & decentral. \\
\hline
\end{tabular}


Continued from previous page

\begin{tabular}{|c|c|c|c|c|c|c|}
\hline $\begin{array}{l}\text { Federal } \\
\text { State }\end{array}$ & City & $\begin{array}{l}\text { Independent } \\
\text { co-ordinating } \\
\text { institution }\end{array}$ & $\begin{array}{l}\text { Central } \\
\text { applica- } \\
\text { tion of } \\
\text { children }\end{array}$ & $\begin{array}{l}\text { Central reg- } \\
\text { istration } \\
\text { spots }\end{array}$ & $\begin{array}{l}\text { Fixed ap- } \\
\text { plication } \\
\text { deadline }\end{array}$ & System \\
\hline & $\begin{array}{l}\text { Offenbach } \\
\text { a.M. }\end{array}$ & yes & yes & yes & yes & central. \\
\hline $\begin{array}{l}\text { Rhineland- } \\
\text { Palatinate }\end{array}$ & Mainz & yes & yes & yes & no & central. \\
\hline Saarland & Saarbrücken & no & no & yes & no & decentral. \\
\hline Baden- & Stuttgart & no & yes & yes & yes & decentral. \\
\hline Wuerttem- & Karlsruhe & yes & no & yes & yes & central. \\
\hline \multirow[t]{5}{*}{ berg } & Freiburg & yes & yes & yes & yes & central. \\
\hline & Heidelberg & no & no & no & no & decentral. \\
\hline & Heilbronn & no & no & yes & yes & decentral. \\
\hline & Ulm & no & no & no & no & decentral. \\
\hline & Pforzheim & yes & yes & yes & yes & central. \\
\hline \multirow[t]{6}{*}{ Bavaria } & Munich & no & no & no & yes & decentral. \\
\hline & Nuremberg & no & no & no & yes & decentral. \\
\hline & Augsburg & no & no & no & yes & decentral. \\
\hline & Regensburg & no & no & no & no & decentral. \\
\hline & Würzburg & no & no & yes & no & decentral. \\
\hline & Ingolstadt & no & no & no & yes & decentral. \\
\hline $\begin{array}{l}\text { Mecklenburg- } \\
\text { Hither } \\
\text { Pomerania }\end{array}$ & Rostock & no & no & no & no & decentral. \\
\hline Saxony- & Halle & yes & yes & yes & no & central. \\
\hline Anhalt & Magdeburg & yes & yes & yes & no & central. \\
\hline Brandenburg & Potsdam & no & no & no & no & decentral. \\
\hline Berlin & Berlin & no & yes & no & no & decentral. \\
\hline \multirow[t]{3}{*}{ Saxony } & Leipzig & yes & yes & yes & no & central. \\
\hline & Dresden & yes & yes & yes & no & central. \\
\hline & Chemnitz & yes & yes & yes & yes & central. \\
\hline
\end{tabular}

*Note: We had no information on the cities Essen, Aachen, Neuss, Ludwigshafen, Mannheim, and Erfurt. 
Table 2: Data description of the variables used

\begin{tabular}{|c|c|c|c|}
\hline Variable name & Description & Value/Type & Comment \\
\hline \multicolumn{4}{|l|}{ Panel $A$} \\
\hline id number & $\begin{array}{l}\text { identifier for children, tie } \\
\text { breaker } 11 \text { in case day- } \\
\text { care centers are indif- } \\
\text { ferent between children } \\
\text { (inducing strict prefer- } \\
\text { ences) }\end{array}$ & $\begin{array}{l}\text { discrete interval }\left[\begin{array}{ll}1, & n\end{array}\right] \\
\text { with } n=100\end{array}$ & $\begin{array}{l}\text { can be assigned based on } \\
\text { "first come, first served } \\
\text { basis" or randomly }\end{array}$ \\
\hline priority leve 12 & $\begin{array}{l}\text { splits children into eight } \\
\text { groups based on occupa- } \\
\text { tional situation of their } \\
\text { parents }\end{array}$ & $\begin{array}{l}\text { discrete interval }[0,7] \text {, } \\
\left.0 \text { : highest priority }{ }^{13}\right] \\
\ldots \\
7 \text { : lowest priority }{ }^{14}\end{array}$ & $U[0,7]$ \\
\hline distance & $\begin{array}{l}\text { measures the distance } \\
\text { from a child's home to } \\
\text { every daycare center in } \\
\mathrm{km}\end{array}$ & $\begin{array}{l}\text { continuous interval } \\
{[0,10]}\end{array}$ & $\begin{array}{l}U[0,10] \text {, in agglomera- } \\
\text { tion scenario "Top" the } \\
\text { distance to Daycare } 1 \text { is } \\
\text { divided by } 10\end{array}$ \\
\hline personality rating & $\begin{array}{l}\text { indicates how a given } \\
\text { daycare center specifi- } \\
\text { cally rates a child's per- } \\
\text { sonality } 15\end{array}$ & $\begin{array}{l}\text { discrete interval }[0,5] \text {, } \\
0 \text { : highest rating } \\
\ldots \\
5 \text { : lowest rating }\end{array}$ & $U[0,5]$ \\
\hline sibling & $\begin{array}{l}\text { indicates whether a child } \\
\text { already has a sibling(s) } \\
\text { at a given daycare cen- } \\
\text { ter }^{16}\end{array}$ & $\begin{array}{l}\text { dummy variable }[0,1] \text {, } \\
0 \text { : no sibling present } \\
\text { 1: sibling present }\end{array}$ & $U[0,1]$ \\
\hline $\begin{array}{l}\text { choice (family's } \\
\text { preference) }\end{array}$ & $\begin{array}{l}\text { shows which daycare fa- } \\
\text { cility a family nominates } \\
\text { as first choice, second } \\
\text { choice, etc. depending } \\
\text { on distance }{ }^{17}\end{array}$ & $\begin{array}{l}\text { discrete interval }[1, n] \\
\text { with } n=3 \text { or } n=5 \\
\text { or } n=10 \text {, based on how } \\
\text { many daycare centers are } \\
\text { considered }\end{array}$ & $\begin{array}{l}\text { merely reflects a ranking } \\
\text { of the distances to the } \\
\text { daycare facilities }\end{array}$ \\
\hline $\begin{array}{lr}\text { ranking } & \text { (daycare } \\
\text { facility's } & \text { prefer- } \\
\text { ences) } & \end{array}$ & $\begin{array}{l}\text { shows children's posi- } \\
\text { tions on the different } \\
\text { daycare centers' ranking } \\
\text { lists and order of spot of- } \\
\text { fering }\end{array}$ & $\begin{array}{l}\text { discrete interval starting } \\
\text { with } 1 \text { as highest rank } \\
\text { (followed by lower ranks) }\end{array}$ & $\begin{array}{l}\text { defined on the basis of } \\
\text { daycare centers' prefer- } \\
\text { ences over child charac- } \\
\text { teristics }\end{array}$ \\
\hline
\end{tabular}

Continued on next page

\footnotetext{
${ }^{11}$ Single tie breaking is applied, if necessary, such that each child has the same initial id that is drawn on for tie breaking at every daycare center, a concept addressed by Abdulkadiroglu et al. (2009).

12 according to the "General admission criteria for daycare facilities with the city of Hanover as the funding body" by the Department of Youth and Family (2004)

${ }^{13} \mathrm{~A}$ child lives with a single parent.

${ }^{14}$ Both parents are at home and neither one is able to work.

${ }^{15}$ This subconscious and very subjective rating by the staff is unobservable for the parents.

${ }^{16}$ If a child already has a sibling at a daycare facility, the facility will prefer this child over a child with no present siblings. We further assume that parents nominate a center as first choice, if a child's sibling is already enrolled there. Thus, if no sibling is enrolled in the favorite daycare facility, then there will also be no sibling enrolled in any other facility.

${ }^{17}$ We assume that the closer a daycare center is located to a child's home, the higher the parents' preference for this facility becomes. This is designed in line with daycare staff's preferences for children living near by.
} 
Continued from previous page

\begin{tabular}{|c|c|c|c|}
\hline Variable name & Description & Value/Type & Comment \\
\hline \multicolumn{4}{|c|}{ Panel B - The "Random" Scenario } \\
\hline $\begin{array}{l}\text { random with } \\
\text { daycare centers }\end{array}$ & $\begin{array}{l}\text { simulates whether a child } \\
\text { applies to only two in- } \\
\text { stead of all three daycare } \\
\text { facilities }\end{array}$ & $\begin{array}{l}\text { dummy variable }[0,1] \text {, } \\
0 \text { : keep all choices } \\
\text { 1: delete choice } 3\end{array}$ & $U[0,1]$ \\
\hline $\begin{array}{l}\text { random with } \\
\text { daycare centers }\end{array}$ & $\begin{array}{l}5 \text { simulates whether a } \\
\text { child applies to only } \\
\text { three/four instead of all } \\
\text { five daycare facilities }\end{array}$ & $\begin{array}{l}\text { discrete interval }[0,2] \text {, } \\
0: \text { keep all choices } \\
\text { 1: delete choice } 5 \\
\text { 2: delete choices } 4-5\end{array}$ & $U[0,2]$ \\
\hline $\begin{array}{l}\text { random with } 1 \\
\text { daycare centers }\end{array}$ & $\begin{array}{l}\text { simulates whether a child } \\
\text { applies to only six/eight } \\
\text { instead of all ten daycare } \\
\text { facilities }\end{array}$ & $\begin{array}{l}\text { discrete interval }[0,2] \text {, } \\
0: \text { keep all choices } \\
\text { 1: delete choices } 9-10 \\
\text { 2: delete choices } 7-10\end{array}$ & $U[0,2]$ \\
\hline
\end{tabular}


Table 3: Share of allocated children matched to their $i^{\text {th }}$ choice child care center (in \%, rounded to one decimal, means of 200 replications)

\begin{tabular}{|c|c|c|c|c|c|c|c|}
\hline \multicolumn{8}{|c|}{3 Daycare centers } \\
\hline \multirow[b]{2}{*}{ Scenario* } & \multirow[b]{2}{*}{ Choice $i$} & \multicolumn{2}{|c|}{50 spots } & \multicolumn{2}{|c|}{65 spots } & \multicolumn{2}{|c|}{90 spots } \\
\hline & & Central. & Decentral. & Central. & Decentral. & Central. & Decentral. \\
\hline \multirow[t]{3}{*}{ Basic } & First & 93.6 & 84.6 & 94.3 & 87.1 & 94.8 & 88.3 \\
\hline & Second & 6.4 & 10.0 & 5.7 & 8.3 & 5.2 & 7.6 \\
\hline & Third & 0.0 & 5.4 & 0.0 & 4.6 & 0.0 & 4.1 \\
\hline \multirow[t]{3}{*}{ Random $^{1}$} & First & 93.6 & 86.7 & 94.3 & 88.7 & 94.8 & 89.5 \\
\hline & Second & 6.4 & 10.6 & 5.7 & 8.8 & 5.2 & 8.3 \\
\hline & Third & 0.0 & 2.8 & 0.0 & 2.4 & 0.0 & 2.2 \\
\hline \multirow[t]{3}{*}{$\mathrm{Top}^{2}$} & First & 42.3 & 41.4 & 44.0 & 43.1 & 43.3 & 42.6 \\
\hline & Second & 57.7 & 45.4 & 56.0 & 45.0 & 56.2 & 47.5 \\
\hline & Third & 0.0 & 13.2 & 0.0 & 11.9 & 0.0 & 9.9 \\
\hline
\end{tabular}

\footnotetext{
${ }^{1}$ Some children do not apply to all 3 daycare facilities but only to 2 .

${ }^{2}$ Daycare center 1 lies in a crowded area and is thus the closest/favorite one for most children.
}

\begin{tabular}{llllllll}
\hline \hline \multicolumn{7}{c}{ 5 Daycare centers } \\
\hline \hline Scenario* & 50 spots & \multicolumn{2}{c}{ 65 spots } & \multicolumn{3}{c}{ 90 spots } \\
\hline Basic & Choice $i$ & Central. & Decentral. & Central. & Decentral. & Central. & Decentral. \\
& First & 91.3 & 75.7 & 92.3 & 77.2 & 92.6 & 80.8 \\
& Second & 8.7 & 10.6 & 7.7 & 10.5 & 6.7 & 9.0 \\
& Third & 0.0 & 6.4 & 0.0 & 5.9 & 0.0 & 4.9 \\
& Fourth & 0.0 & 4.3 & 0.0 & 3.8 & 0.0 & 3.0 \\
& Fifth & 0.0 & 3.1 & 0.0 & 2.6 & 0.0 & 2.3 \\
\hline Random $^{1}$ & First & 91.3 & 78.2 & 92.3 & 79.4 & 92.6 & 82.4 \\
& Second & 8.7 & 11.2 & 7.7 & 11.0 & 6.7 & 9.1 \\
& Third & 0.0 & 6.5 & 0.0 & 5.8 & 0.0 & 5.3 \\
& Fourth & 0.0 & 3.3 & 0.0 & 3.1 & 0.0 & 2.6 \\
& Fifth & 0.0 & 0.8 & 0.0 & 0.6 & 0.0 & 0.7 \\
\hline Top ${ }^{2}$ & First & 38.8 & 35.2 & 38.6 & 35.0 & 37.8 & 35.3 \\
& Second & 61.2 & 34.2 & 61.3 & 36.9 & 59.8 & 40.9 \\
& Third & 0.0 & 15.6 & 0.0 & 14.8 & 0.0 & 12.6 \\
& Fourth & 0.0 & 8.9 & 0.0 & 8.3 & 0.0 & 6.8 \\
& Fifth & 0.0 & 6.2 & 0.0 & 5.0 & 0.0 & 4.3 \\
\hline
\end{tabular}

${ }^{1}$ Some children do not apply to all 5 daycare facilities but only to 3 or 4 .

${ }^{2}$ Daycare center 1 lies in a crowded area and is thus the closest/favorite one for most children. 


\begin{tabular}{|c|c|c|c|c|c|c|c|}
\hline \multicolumn{8}{|c|}{10 Daycare centers } \\
\hline \multirow[b]{2}{*}{ Scenario* } & \multirow[b]{2}{*}{ Choice $i$} & \multicolumn{2}{|c|}{50 spots } & \multicolumn{2}{|c|}{65 spots } & \multicolumn{2}{|c|}{90 spots } \\
\hline & & Central. & Decentral. & Central. & Decentral. & Central. & Decentral. \\
\hline \multirow[t]{10}{*}{ Basic } & First & 86.9 & 62.6 & 88.1 & 64.7 & 88.0 & 67.0 \\
\hline & Second & 13.1 & 10.9 & 11.8 & 10.6 & 8.9 & 10.4 \\
\hline & Third & 0.0 & 6.8 & 0.0 & 6.6 & 0.0 & 6.5 \\
\hline & Fourth & 0.0 & 5.6 & 0.0 & 5.3 & 0.0 & 4.8 \\
\hline & Fifth & 0.0 & 3.9 & 0.0 & 3.5 & 0.0 & 3.2 \\
\hline & Sixth & 0.0 & 3.0 & 0.0 & 2.8 & 0.0 & 2.3 \\
\hline & Seventh & 0.0 & 2.5 & 0.0 & 2.1 & 0.0 & 1.9 \\
\hline & Eighth & 0.0 & 2.0 & 0.0 & 1.9 & 0.0 & 1.7 \\
\hline & Ninth & 0.0 & 1.6 & 0.0 & 1.4 & 0.0 & 1.2 \\
\hline & Tenth & 0.0 & 1.3 & 0.0 & 1.2 & 0.0 & 1.0 \\
\hline \multirow[t]{10}{*}{ Random $^{1}$} & First & 86.9 & 64.4 & 88.1 & 66.4 & 88.0 & 69.1 \\
\hline & Second & 13.1 & 11.9 & 11.8 & 11.2 & 8.9 & 10.7 \\
\hline & Third & 0.0 & 7.2 & 0.0 & 7.0 & 0.0 & 6.7 \\
\hline & Fourth & 0.0 & 5.6 & 0.0 & 5.2 & 0.0 & 4.6 \\
\hline & Fifth & 0.0 & 4.0 & 0.0 & 3.8 & 0.0 & 3.1 \\
\hline & Sixth & 0.0 & 2.9 & 0.0 & 2.7 & 0.0 & 2.3 \\
\hline & Seventh & 0.0 & 1.7 & 0.0 & 1.4 & 0.0 & 1.5 \\
\hline & Eighth & 0.0 & 1.5 & 0.0 & 1.5 & 0.0 & 1.4 \\
\hline & Ninth & 0.0 & 0.5 & 0.0 & 0.4 & 0.0 & 0.3 \\
\hline & Tenth & 0.0 & 0.5 & 0.0 & 0.3 & 0.0 & 0.2 \\
\hline \multirow[t]{10}{*}{ Top $^{2}$} & First & 46.4 & 33.5 & 46.0 & 34.6 & 42.8 & 34.6 \\
\hline & Second & 53.3 & 19.5 & 52.4 & 20.9 & 50.2 & 23.4 \\
\hline & Third & 0.0 & 13.8 & 0.0 & 13.7 & 0.0 & 14.0 \\
\hline & Fourth & 0.0 & 9.9 & 0.0 & 9.5 & 0.0 & 9.3 \\
\hline & Fifth & 0.0 & 7.0 & 0.0 & 6.8 & 0.0 & 5.9 \\
\hline & Sixth & 0.0 & 5.2 & 0.0 & 4.5 & 0.0 & 4.0 \\
\hline & Seventh & 0.0 & 3.8 & 0.0 & 3.4 & 0.0 & 3.1 \\
\hline & Eighth & 0.0 & 2.9 & 0.0 & 2.8 & 0.0 & 2.4 \\
\hline & Ninth & 0.0 & 2.4 & 0.0 & 2.2 & 0.0 & 1.8 \\
\hline & Tenth & 0.0 & 1.9 & 0.0 & 1.7 & 0.0 & 1.5 \\
\hline
\end{tabular}

* Note: All scenarios assume daycare centers of approx. equal size, 100 applying children, and the following child characteristics based on which the daycare centers' staff pick the children (in descending order of relevance): - generally valid priority level - present sibling(s) - daycare specific rating of child's personality (unknown to parents) - distance to daycare centers (in $\mathrm{km}$ ) - id number 